\title{
Technologies for ensuring financial security of the banking system in conditions of informational alteration of business
}

\author{
Larisa Andreeva ${ }^{1}$, Arthur Alukhanyan $^{2}$, Olga Andreeva ${ }^{1 *}$, and Anfisa Selivanova ${ }^{1}$ \\ ${ }^{1}$ Rostov State Transport University, 2 pl. Rostovskogo Strelkovogo Polka Narodnogo Opolcheniya, \\ Rostov-on-Don, 344038, Russia \\ ${ }^{2}$ Don State Technical University, sq. Gagarina, 1, Rostov-on-Don, 344010, Russia
}

\begin{abstract}
The article is devoted to the assessment of technologies, tools and methods for ensuring financial security of the banking system in modern conditions of business digitalization and informational transformation. Relevance of the topic is caused by the fact that financial security of the banking business entirely depends not only on digital tools of provision, financial sovereignty, state of economy, but also on force of geopolitical risks. Growing risks and threats in the finance sector heighten objectively the research interest in this issue when external sanction pressure on domestic banking system from the part of global market players increases. Imbalances in the global financial system, severe consequences of pandemic crisis, slowdown in the economy growth rate, decline in employment and inflation growth, as well as other factors determine the need to apply more rigid regulatory tools aimed at blocking negative trends.
\end{abstract}

\section{Introduction}

Informational transformation of the banking business has been dynamically taken place in global economy for several decades. Not only new models for the banking business development based on innovative technologies of informatization and digitalization, but also complex structural changes in development of financial and credit institutions emerged. Global trends, on the one hand, enhanced the interdependence and interdetermination of world and national banking institutions, and on the other hand, created new risks which are difficult to manage, determining the need for continuous control over financial and information flows in monetary policy and banking business, which became high-tech. Relevance of the issue is enhanced by the fact of making by the European Parliament a proposal to its resolution to disconnect the Russian Federation from the SWIFT. The consequences of such decision can establish complex risks for export-import settlements. The article determines that in case issuing by the developed countries of their own digital currencies, SWIFT may lose its universal competitive advantages.

Existing information and network structure of the banking business creates certain difficulties and restrictions in system management in conditions of high dynamics of digital

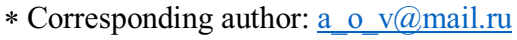


economy growth, showed by the pandemic crisis ongoing worldwide. Large banks are transforming their business into digital ecosystems based on digital tools.

Deep informational transformation of financial business, emergence of new technologies for interaction between banking institutions of different countries, macro-regulators and business communities have identified a vector transition to a new format for global financial relations development. In the global financial market new directions of information and financial control over banking transactions in the spirit of neodirigisme and forced imposition of new monetary policy models emerged.

\section{Materials and methods}

Study of forms and directions of the banking business informational transformation was undertaken with the use of the following open and verifiable sources: publications included in the global abstract and citation databases Scopus and Web of Science, as well as publications included in the Russian Science Citation Index, in the part of publications on the challenges of assessing directions, methods, tools and technologies of financial business informational transformation and identification of development features of banking institutions of world and national levels related with network technologies of control over the flow of financial and information transactions. As a part of the study the following methods were applied: comparative analysis, institutional design, cognitive analysis, theory of information management and risk-oriented approach, risk-oriented development, philosophy of economy, and anti-crisis management.

Prerequisites for development of the study's methodological base were directions and tools for development of financial and information economy, neodirigisme in the era of digital transformation, financial controlling, and information management. The following categories had particular significance in the course of the study: "financial security", "global financial economics", "risk management", "network control", "crisis" "risk-oriented development", and "financial behavior".

Results of the study can be used in generalized form in management and financial environment for development of anti-crisis methods for banking regulation, technologies of ensuring financial security of credit institutions and banking transactions, formation of stable national financial and credit systems, as well as risk-oriented model of financial behavior of the operators on the globalizing market.

\section{Results}

Main contribution of the study is to identify changes in the mechanism of information and financial management of large systems aimed at ensuring their financial security and anticrisis stability. When implementing the strategy of financial security, according to the analysts, the banks increasingly feel dependence on the global financial economy, transformational trends, which, according to the scientists, change business based on expanding digital technologies of risk management. [1-9]

With the purpose to ensure financial security of domestic banking system as a long-term program of the anti-crisis financial regulation, in August 2020 the Bank of Russia decided to extend the supporting measures of financial system, first of all the "anti-coronavirus" supporting measures, including whole range of regulatory exemption, reduction of requirements for reserves, indulgence on reserves and assets reassessment, as well as loan restructuring programs. Extension of supporting measures helped to retain financial stability of Russian credit organizations, support the level of banking assets capitalization and improve financial results of their operation. The consequences of the banks' reaction to the 
crisis were controversial. Adopted restrictions on the execution of banking transactions in conditions of reaction to the COVID-19 pandemic are presented in figure 1 .

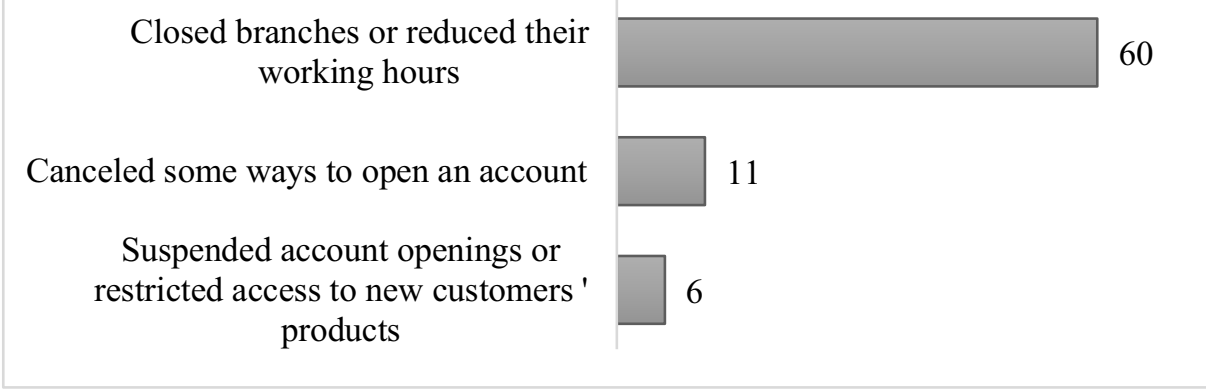

Fig. 1. Adopted restrictions on execution of banking transactions in crisis.

Currently as a result of the situation improvement the Bank of Russia has already transformed a number of decisions established to stabilize the situation in financial market existed due to the pandemic crisis. In particular, creation of the reserves on loans, which were restructured before December 31, 2020 was extended for the banks until July 1, 2021. Thus, until year-end on banker's books, it is possible not to refer a loan granted to the borrower to the category of restructured loans; therefore, it is possible not to define a debt burden indicator on this loan. In general, the factor of deadlines extension figured largely for the banks to ensure financial security, since credit organizations usually postpone creation of the reserves. In connection with this factor, this procedure is not accompanied by the developed schedules. Banks experiencing difficulties with business processes in crisis conditions began to apply a number of innovations in practical activities (figure 2).

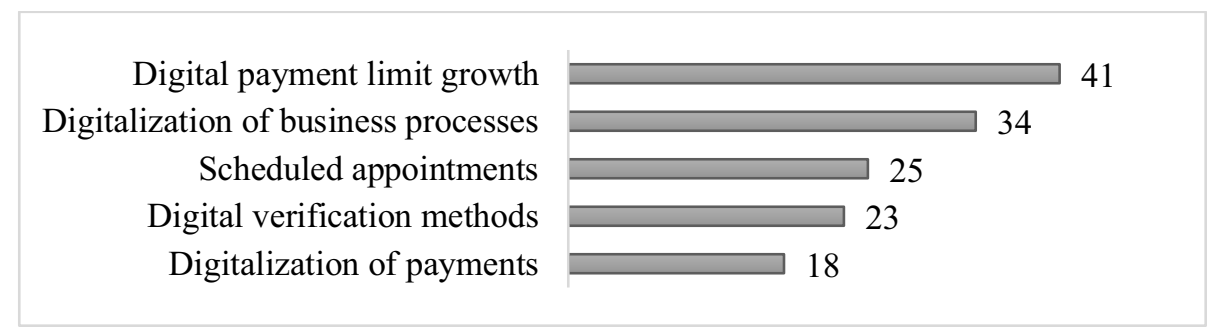

Fig. 2. Modernization of banking business-processes in crisis.

One can assume that the macro-regulator did not plan to indicate strictly the declared date of formation. Note that the volume of reserves may be large and poorly regulated across the entire national banking system. In the system of supporting anti-crisis activities, which, according to the macro-regulator, have lost their relevance, were measures related to restrictions on the fee amount for the acquiring when shopping online and paying for medical services, introduced during the coronavirus crisis.

For development of financial market, it is advisable, that after cancellation of restrictions from the part of the Bank of Russia credit organizations returned to widespread use of the loyalty programs and enhanced consumers' interest in non-cash payments expansion. It should be clarified, that basic measures to support the borrowers and customers are prescribed as recommendations for the banks, which they may apply or not apply. The number of the banks' clients, dissatisfied with the quality of service during the pandemic crisis period, has increased. The content of the borrowers' claims is associated with refusal to restructure the loans. Reduction in the procedures of the banking licenses revocation could be observed in 
the Russian financial market during the pandemic. This situation was related with lack of inspections of the banks ensuring the information constituent for the adoption of such supervisory decisions. The decision of the Bank of Russia to maintain grace requirements until December 31, 2020 became an important constituent of the implemented measures to support financial system.

This means, that domestic banks continued the policy of restructuring loans without establishing fines and penalties. In the meantime, the requirement for creation of the reserves on such loans in full is postponed by the macro-regulator until July 1, 2021. The decision of the Bank of Russia on the system support of domestic consumer credit market by reducing the premiums to the risk coefficients on unsecured consumer loans also reduced credit risks of the Russian market. These decisions were deliberate.

These decisions can be called system due to the fact that these measures were associated with the indicator of limit debt burden of the banks' clients, the level of which the premiums always depend on. If the "poor-quality borrowers" risks increase, the credit market will lose stability and a bankruptcy wave will start. If the "high-quality borrowers'" risks rise, there will be a decrease in dynamics of the market for a long term. The Bank of Russia canceled the introduced premiums on the loans granted before August 31, 2020, which increased capitalization of the Russian banks by more than 160 billion rubles of the capital. [10]

In 2020 in relation with transition of the Bank of Russia to a soft monetary policy, aimed at active stimulation of the Russian economy in pandemic and restrictive measures introduced in connection with this infection, for example, the macro-regulator reduced the key rate in total by 2 percentage points. Note that by July 24, 2020, this rate reached the minimum historical value of $4.25 \%$ per annum. Having made this decision, the Bank of Russia as a macro-regulator kept the key rate unchanged four consecutive times, but on March 19, 2021 it decided to increase the key rate by 0.25 percentage points. Currently, this indicator amounts to $5 \%$ per annum.

Note that last time the macro-regulator decided to increase the key rate in December 2018. The key rate in that period difficult for the Russian economy development was raised from $7.5 \%$ to $7.75 \%$ per annum. The Bank of Russia grounded the adopted decision on the increase of the key rate in March 2021 by the following two main factors: high rates of domestic demand recovery in the Russian market, rising inflation and increasing inflation pressure on the Russian economy.

Upon expert findings of the Bank of Russia, during I quarter of 2021 the growth rate in consumer prices in Russian market was higher than the macro-regulator's analytical forecast. Post-crisis pace of domestic demand recovery became of dynamic and stable nature. Increase in demand in a number of domestic economy sectors is being implemented with an advanced pace and ahead of production growth. Macroeconomic expectations for external demand are positive as a result of the implemented measures of financial support in a number of countries and expansion of the population's vaccination area. Significant rise in inflationary expectations of the market economic agents acts as actual constituent of the decision by the Bank's of Russia Board of Directors on the key rate increase. An increase in the key rate means transition from a soft monetary policy to neutral one. A return of the Bank's of Russia key rate to the level of 5-6\% per annum can be expected in near future.

Dynamics of increasing the key rate to neutral level depends, first of all, on the level of inflation. According to the average daily data of the Rosstat, annual inflation in Russia on March 15, 2021 remained at maximum level from November 2016, when this indicator was $5.8 \%$. At the meeting on February 12, 2021, the Bank of Russia provided information on the fact that the level of disinflation risks decreased at that time, and the balance of risks shifted towards the pro-inflationary risks.

In April 2021, the international rating agency Moody's changed the forecast for the Russian banking sector development from "negative" to "stable" in the updated report. Such 
an optimistic decision of the rating agency was related with consistent cancellation of the introduced restrictions (lock down), improvement of the macroeconomic situation, as well as rapid recovery of financial and credit sector, and global oil market growth, which contributed to the Russian ruble exchange rate strengthening. Russian banks began to expand the volume of lending during the crisis, which was related with increase of the demand from the part of customers and development of the business supporting programs, announced by the government.

At the same time, with development of the banking lending, the banks' credit risks began to increase and quality of the loans began to worsen. As the main risk which may lead to an increase in the number and volume of challenging loans, the analysts consider the continued drop in the Russian citizens' income, which reduces quality of servicing the loans: according to the Credit Suisse's research, the revenues of Russian citizens decreased on average by 24 $\%$ during the pandemic.

In the Russian Federation, the inflation growth has increased since the end of 2020, which limits the citizens' real incomes rise and the companies' financial security. Cancellation of the state anti-crisis supporting measures for the banks and their clients will contribute to deepening of the imbalances in financial and credit sector. Almost $20 \%$ of the restructured loans total volume can turn out to be risky. This situation will contribute to rapid washing from the market of small-format banks and growth of bankruptcy of the companies from the small and medium business segment. Cancellation of state financial supporting measures may cause a decrease in financial stability of small credit organizations because of lack of the resources for supplementing and creating reserves. However, the most difficult risk of financial security of the Russian banking system is the risk of isolation from the global information and service center. The risk of disconnecting Russian banks from the SWIFT is one of the most serious sanction risks. Implementation of this risk can lead to suspension in international settlements, and will inevitably cause violation in supply chains, rise in prices for import, and shortage of individual commodity groups.

\section{Discussion}

During the crisis the state increased the costs on state support for the economy, including at the expense of the Sovereign Welfare Fund. As a result of suspension of a large number of Russian companies' operation, relevance of the tasks of the Russian banking system's financial security technological ensuring increased. The CEO of the Analytical Credit Rating Agency (ACRA) M. Sukhov notes that with presence of the restrictions related to the business operation, the risks requiring regulation arise; the effect of "neck" appears in the market, despite the fact that the Russian government's package of anti-crisis measures increases. The analysts from the Bank of America estimated the total amount of direct fiscal costs for three anti-crisis packages aimed to support business and population at 2-2.2 trillion rubles or $2 \%$ of GDP. The Russian Federation Government estimated the amount of state support in general within the first two packages in 2.1 trillion rubles; the value of the third package was not announced officially. [11]

With increasing risks, the Bank of Russia changed the monetary policy vector existing before the pandemic crisis; the macro-regulator will be forced to raise the key rate. Ruble devaluation can also be expected, which will lead to the growth in prices, causing badly regulated complex inflationary risks reducing financial security and financial stability of the banking system. Disconnection from the SWIFT may cause quick discharge by the investors of Russian securities, the fall in the stock market. Strengthening of the global trends increases risks of financial security. Risky effect will come with possible restrictions in the transfers abroad. According to the experts, reduction in financial stability of companies will cause losses of the banks, which are the main holders of corporate and state securities. [12] 
In 2021 administrative costs will have pressure on the banks' profit, to reduce which, with the best will in the world, will not be possible. This will occur, firstly, by accelerating inflation, and secondly, because of the need to pay dividends and premiums which were greatly reduced in 2020. Evaluating efficiency of the anti-crisis regulation measures of financial and credit sector, it is important to take into account a fairly limited role of credit organizations in the economic behavior of clients, first of all, individuals. The customers of such kind do not want to depend strongly on credit organizations, preferring maintaining financial security when acquiring goods and services in terms of restrictions. Currently the services of commercial banks contain additional risks for the clients: cost of loans is high, and return on deposits is low. After introducing digital ruble in the Russian market, when all the banking transactions are absolutely transparent, demand for the credit organizations services will decrease. This is connected with the features of transactions with this kind of financial tools. They consist in the fact that the Bank of Russia will keep digital currency on its accounts. At the same time, it will be quite convenient to open access to digital currency for settlements using this tool through financial intermediaries, having the right to use ewallets.

The informational transformation determines the need for the credit organizations to undertake a system reorganization of interaction with clients based on the anti-crisis reorganization of business. [13] Rapidly developing digitalization technologies have largely expanded the range of financial services for the clients of banks, leaving in the past the benefits of credit and deposit banking cards. Penetrating the market, digital technologies secured advantages of these tools for a certain time, but today new tools are required to ensure competitive position in the market. Recurrent financial risks in economy and society in the information and financial globalization, suggest application of new technologies. [14]

Risks limiting dynamics of financial security are also related with quality of the balance of payments. According to the analytical data of the Bank of Russia, in January-April 2021 "positive balance of the current account of the Russian Federation's balance of payments remained at the level of the corresponding indicator of 2020 and amounted to 28.1 billion US dollars". [15]

If before the pandemic crisis the banking cards served as a practically innovative financial tool for ensuring settlements, then during the crisis a contactless payment tool appeared, which is expanding based on use of the smartphones. At the same time, for the user of this system there is no special difference in the etymology of this tool. It does not matter for the user based on which tools the required transaction is carried out. The main thing for the client is that the access to the transaction was safe and convenient. The payments providers can be both credit organizations and information and service companies, such as Apple, Amazon, PayPal or other structures. The bank institutions are not indispensable providers for the acquiring financial services in information and service economy. There is no need for potential consumers of financial services to use the services of credit organizations. The process of payment, including with involvement of credit funds, is included in the structure of other innovative information and financial products. Service financial companies strongly compete with commercial banks; at the same time currently the banks themselves seek to become high-tech companies in order to ensure financial security.

\section{Conclusions}

Based on the above restrictions of the Russian economy development and conditions of the banking sector operation, it is obvious, that domestic credit institutions should undertake accelerated information and financial modernization, becoming information and service organizations to greater extent. If commercial banks are not integrated into the information transformation processes, they will lose most clients, because the risks of financial security 
will increase. Profitability of these services increases the profits to the banks and to a greater extent increases the risks of the clients who cannot become high-quality counterparties due to debt overburden or absence of quality pledges.

Commercial banks, having limited goal, related with ensuring their business marginality, will soon lose the opportunity to attract large audience of customers who need credit, deposit or service products. Thus, after cancellation of all restrictions introduced by the Bank of Russia, increased regulation and controlling measures related with the licenses revocation can be expected. Such measures are implemented as a part of financial controlling.

For the client, safety related to financial, information, consulting, and transactional operations is becoming the basis of the modern bank competitiveness in the market. The banks should learn to manage financial security based on new digital tools in the course of business transformation. This means that, to ensure financial security competitive banks should design their own ecosystems, in which modern financial tools play only a supporting role for technological operations and strategic development.

At the stage of the mobile banking development the banking sector did not manage in full with the task of reducing the outflow of strategic clients, attractive for financial business. The economic agents of financial market make financial transactions in trading places. The credit organizations' clients use banking applications in case they need to clarify the movement of funds in accounts or check the balance of the account on a certain date. In order to expand their market share, financial and technological companies are developing and implementing a new concept of information and network development. These development strategies are based on new information management technologies and innovative service, meeting the growing clients' demand for operational products and services. Such technologies are the basis of the solutions of such market operators as the Buy-Now-Pay-Later, solutions of the Zippay, AfterPay, which, in terms of the business informational transformation are ahead of classical banks in financial functionality of information and service operations.

Thus, developing technologies of ensuring the banking system's financial security as a part of the anti-crisis strategy, the Bank of Russia as a macro-regulator and the Russian Federation Government use a strategic vector of regulation, related with information transformation of business and modern system of geopolitical and internal risks management.

Modern strategy of ensuring the banking business's financial security is being formed based on the concept of information and financial, aimed at protection of the country's financial sovereignty, state of economy and power of geopolitical risks. Sanations, risks and outflow of capital from the Russian banking sector create certain imbalances in the monetary system, which increased greatly during the pandemic period. The need to form a new algorithm of ensuring financial security determines the vector of change in the Russian market economic agents' behavior.

\section{References}

1. M. Ziolo, B.Z. Filipiak, B. Tundys, Sustainability in Bank and Corporate Business Models. The Link between ESG Risk Assessment and Corporate Sustainability (2021) doi: 10.1007/978-3-030-72098-8

2. L. Andreeva, T. Epifanova, O. Andreeva, A. Orobinsky, Contemporary Issues in Business and Financial Management in Eastern Europe, 100, 49-60 (2018)

3. S.J. Kaur, L. Ali, M.K. Hassan, Md Al-Emran, Journal of Financial Services Marketing, 26, 2, 4, 107-121 (2021)

4. W. Younas, K.R. Kalimuthu, Journal of Financial Services Marketing, 26, 2, 1, 67-80 (2021) 
5. J.J. Canals-Cerda, E. Dolson, Consumer Finance Institute conference summaries, $6(2021)$

6. T. Golovina, I. Avdeeva, L. Parakhina, Central Russian Journal of Social Sciences, 15, 1, 242-254 (2020)

7. D.G. Etse, C. Gozel, Vestnik MIRBIS, 1 (21), 68-75 (2020)

8. E. Krylova, T. Podsvetova, E. Soloviev, Studies in Systems, Decision and Control, 282, 189-196 (2020)

9. O. Ivanova, L. Korobeinikova, I. Risin, E. Sysoeva, Lecture Notes in Networks and Systems, 87, 510-516 (2020)

10. Central Bank Revealed How Much Russians have Invested in "Shadow" Investment Products, Business News Agency PRIME, (2021) https://1 prime.ru/finance/20210121/832864944.html (Date of access 15.03.2021)

11. A. Feinberg, RBC, May 18, (2020) https://www.rbc.ru/finances/18/05/2020/5ec128c49a794781586a5897

12. N. Vovchenko, O. Andreeva, A. Orobinsky, R. Sichev, International Journal of Economics \& Business Administration, VII (1), 3-15 (2019)

13. R. Etembekov, European Journal of Natural History, 1, 13-18 (2021)

14. A. Andreeva, O, Semenyuta, R, Sichev, Y. Filippov, International Journal of Economics and Business Administration, VII (1), 40-52 (2019)

15. Evaluation of Key Aggregate of the Russian Federation's Balance of Payments in January-April 2021, Bank of Russia, https://www.cbr.ru/statistics/macro_itm/svs/bopeval/ 